\title{
Tanggung Jawab Hukum Terhadap Hilangnya Nyawa Orang Di Lubang Tambang Batu Bara Ditinjau Dari Perspektif Hukum Pidana (Studi Kasus PT. Cahaya Energi Mandiri (CEM), kelurahan Sambutan Kecamatan Samarinda Ilir)
}

\author{
Rustiana \\ Rustiana77@gmail.com \\ Dosen Fakultas Hukum \\ Universitas Widya Gama Mahakam Samarinda
}

\begin{abstract}
ABSTRAK
Pemanfaatan sumber daya alam dibidang pertambangan batubara banyak memberikan dampak positif dan dampak negatif. Dampak positif yaitu meningkatkan perkembangan perekonomian dan sosial baik untuk masyarakat dalam hal penyerapan tenaga kerja maupun pemerintah Provinsi Kalimantan Timur dan Daerah kabupaten Kota Penghasil dalam hal Sumber Pendapatan Asli Daerah (PAD). Dampak negatif meliputi rusaknya hutan yang berada di daerah lingkar tambang, tercemarnya laut, terjangkitnya penyakit bagi masyarakat yang bermukim di daerah lingkar tambang, bahkan dampak nyata negative terhadap pertambangan yaitu membuat hilangnya nyawa seseorang akibat lubang bekas tambang, Secara hukum kasus tanggung jawab terhadap hilangnya nyawa orang di lubang tambang batubara pertanggungjawabannya bukan satu orang, tetapi ada beberapa pihak yang bertanggungjawab.

Objek penelitian adalah PT. Cahaya Energi Mandiri, dan Pihak Pemerintah dan kepolisian terkait dengan hilangya nyawa orang di lubang tambang atau di Wilayah Ijin Usaha Pertambangan (IUP) PT. Cahaya Energi Mandiri. Maka tujuan tesis ini yang pertama adalah untuk mengetahui dan menganalisis Tanggung Jawab Hukum Terhadap Hilangnya Nyawa Orang Di Lubang Tambang Batubara Ditinjau Dari Perspektif Hukum Pidana, yang kedua Untuk mengetahui dan menganalisa unsur-unsur tindak pidana dikaitkan dengan bidang pertambangan batubara.

Metode penelitian yang digunakan adalah metode penelitian hukum normatif-empiris yaitu Penggabungan antara pendekatan hukum normatif dengan adanya penambahan dari berbagai unsur-unsur empiris.

Dari hasil penelitian dapat diketahui bahwa hilangnya nyawa orang lubang tambang telah memenuhi unsur - unsur dalam ketentuan hukum pidana , karena hilangnya nyawa orang dilubang tambang telah memenuhi unsur dalam pasal 359 KUHP dam pasal 112 Undang undang Nomor 32 Tahun 2009 tentang Perlindungan Dan Pengelolaan Lingkungan Hidup. Sedangkan pertangungjawaban hukum pidana dapat dikenakan kepada pemegang IUP OP dan Pemerintah selaku pihak yang bertanggungjawab terhadap pengawasan lingkungan hidup dengan pemidaan berupa pidana penjara maupun restitusi atau ganti kerugian terhadap korban atau keluarganya oleh pelaku.
\end{abstract}

Kata Kunci : Tanggung Jawab di lubang tambang 


\begin{abstract}
ABSTRACK
The use of natural resources in coal mining has many positive and negative impacts. The positive impact is increasing economic and social development both for the community in terms of employment and the government of the Province of East Kalimantan and the Regency of the City of the Producer in terms of Regional Original Revenue (ROR). Negative impacts include the destruction of forests in the area around the mine, contamination of the sea, disease outbreaks for people who live in the area around the mine, even the real negative impact on mining that makes the loss of one's life due to ex-mining holes, legally the case of responsibility for loss of life the person in the coal mine pit is not one person responsible, but there are some responsible parties.

The object of research is PT. Cahaya Energi Mandiri, and the Government and the police related to the loss of life of people in mining pits or Mining Business License (IUP) of PT. Cahaya Energi Mandiri. So the purpose of this first thesis is to know and analyze the Legal Responsibility to the Loss of People Life at the Coal Mine Hole Judging from the Perspective of Criminal Law, the second to know and analyze the elements of criminal acts associated with the field of coal mining.

The research method used is the normative-empirical legal research method that is merging between the approach of normative law with the addition of various empirical element.

From the results of the research can be seen that the loss of life of the pit hole people have met the elements in the provisions of criminal law, because the loss of the lives of people perforated mine has met the elements in Article 359 KUHP and article 112 of Law Number 32 Year 2009 on Protection and Environmental Management. While the criminal law responsibility can be imposed on the holders of IUP and the Government as the party responsible for environmental monitoring by punishment in the form of imprisonment or restitution or compensation for the victim or his family by the perpetrator.
\end{abstract}

\title{
Keywords: Responsibility at the pit
}

\section{PENDAHULUAN}

\section{A. Latar Belakang}

Di dalam Undang-undang Dasar Tahun 1945, Pasal 28 B Ayat (2) menyebutkan "bahwa setiap anak berhak atas kelangsungan hidup, tumbuh, dan berkembang serta berhak atas perlindungan dari kekerasan dan diskriminasi". Intinya hak anak dilindungi oleh Negara.

Hak dasar anak yakni hak kelangsungan hidup, tumbuh, dan berkembang semakin terancam oleh pengerusakan lingkungan akibat dari pada pertambangan dengan metode tambang terbuka (Open Pit/surface Mining) yang dilakukan tanpa mengindahkan peraturan yang berlaku yang telah menjadikan banyaknya lahan terbuka dan berlubang seperti yang dapat dilihat di Provinsi Kalimantan Timur (Kaltim).

Pemanfaatan sumber daya alam dibidang pertambangan batubara banyak memberikan dampak positif dan dampak negatif. Dampak positif yaitu meningkatkan perkembangan perekonomian dan sosial baik untuk masyarakat dalam hal penyerapan tenaga kerja maupun pemerintah Provinsi Kalimantan Timur dan Daerah kabupaten Kota Penghasil dalam hal Sumber Pendapatan Asli Daerah (PAD). Dampak negatif meliputi rusaknya hutan yang berada di daerah lingkar 
tambang, tercemarnya laut, terjangkitnya penyakit bagi masyarakat yang bermukim di daerah lingkar tambang, dan konflik antara masyarakat lingkar tambang dengan perusahaan tambang. ${ }^{1}$ Bahkan juga mengancam keberlangsungan hidup anak - anak lingkar tambang seperti insiden yang terjadi di wilayah IUP OP Batubara PT. Cahaya Energi Mandiri (CEM) pada tanggal 25 mei 2015 yang mengorbankan seorang anak bernama Ardi bin hasyim yang berusia 11 (sebelas) tahun yang memiliki kebutuhan khusus, Ia terjatuh dan tenggelam di dalam lubang tambang atau eks galian tambang PT. CEM yang terletak di kelurahan sambutan kecamatan samarinda ilir Kota Samarinda. Berdasarkan Data Dari Komnasham Dan Jatam Daftar Korban Lubang Tambang Batubara kalimantan Timur: ${ }^{2}$ Dapat diuraikan sebagai berikut :

Daftar Korban Lubang Tambang

Batubara Kalimantan Timur. Tabel : I

\begin{tabular}{|c|c|c|c|c|}
\hline No & Perusahaan & Korban & Lokasi & $\begin{array}{l}\text { Waktu } \\
\text { Kejadian }\end{array}$ \\
\hline 1 & PT. Kitadin & $\begin{array}{l}\text { Muh. } \\
\text { Fariqi } \\
\text { (14) }\end{array}$ & $\begin{array}{c}\text { Desa } \\
\text { Bangun } \\
\text { Rejo Kec. } \\
\text { Tenggarong } \\
\text { Sebrang }\end{array}$ & $\begin{array}{c}26 \text { Januari } \\
2012\end{array}$ \\
\hline 2 & $\begin{array}{c}\text { PT. Bara } \\
\text { Sigi Mining } \\
\text { (BSM) }\end{array}$ & $\begin{array}{l}\text { Sanofa } \\
\text { M Rian } \\
\text { (14) }\end{array}$ & \begin{tabular}{|c|} 
Desa \\
Sebulu \\
Modern, RT \\
14 (Jalan \\
Poros \\
tenggarong \\
Sebulu), \\
Kecamatan \\
Sebulu \\
\end{tabular} & $\begin{array}{c}05 \text { Agustus } \\
2015\end{array}$ \\
\hline 3 & $\begin{array}{l}\text { PT. Muliana } \\
\text { Jaya }\end{array}$ & $\begin{array}{c}\text { Budi } \\
\text { Maulana } \\
(11)\end{array}$ & $\begin{array}{l}\text { Kelurahan } \\
\text { Jawa RT.4 } \\
\text { Kecamatan } \\
\text { Sangasanga }\end{array}$ & $\begin{array}{l}\text { Agustus } \\
2013\end{array}$ \\
\hline 4 & $\begin{array}{c}\text { PT. Multi } \\
\text { Harapan } \\
\text { Utama } \\
\text { (MHU) }\end{array}$ & $\begin{array}{l}\text { Mulyadi } \\
\text { (15) }\end{array}$ & $\begin{array}{c}\text { RT.3, } \\
\text { Kelurahan } \\
\text { Loa Ipuh } \\
\text { Darat, } \\
\text { Kecamatan } \\
\text { Tenggarong }\end{array}$ & $\begin{array}{c}16 \\
\text { Desember } \\
2015\end{array}$ \\
\hline 5 & $\begin{array}{c}\text { KSU Wijaya } \\
\text { Kusuma }\end{array}$ & $\begin{array}{c}\text { Dewi } \\
\text { Ratna (9) }\end{array}$ & $\begin{array}{c}\text { Desa } \\
\text { Sumber Sari } \\
\text { Kec. Sebulu }\end{array}$ & $\begin{array}{c}30 \\
\text { Desember } \\
2015\end{array}$ \\
\hline
\end{tabular}

\begin{tabular}{|c|c|c|c|c|}
\hline 6 & $\begin{array}{c}\text { PT. Bukit } \\
\text { Baiduri } \\
\text { Energi }\end{array}$ & $\begin{array}{c}\text { Noval } \\
\text { Fajar } \\
\text { Slamat } \\
\text { Riyadi } \\
(15) \\
\end{array}$ & \begin{tabular}{|c|} 
Desa Bukit \\
Raya RT.19 \\
Kec. \\
Tenggarong \\
Sebrang \\
\end{tabular} & $\begin{array}{l}23 \text { Maret } \\
2016\end{array}$ \\
\hline 7 & $\begin{array}{l}\text { PT. Bukit } \\
\text { Baiduri }\end{array}$ & $\begin{array}{c}\text { Diky } \\
\text { Aditya } \\
(15)\end{array}$ & $\begin{array}{c}\text { Desa Bukit } \\
\text { Raya RT.19 }\end{array}$ & $\begin{array}{c}23 \text { Maret } \\
2016\end{array}$ \\
\hline 8 & PT. Kitadin & $\begin{array}{c}\text { Tidak } \\
\text { Teridenti } \\
\text { fikasi }\end{array}$ & $\begin{array}{c}\text { Tenggarong } \\
\text { Sebrang, } \\
\text { Kutai } \\
\text { Kertanegar } \\
\text { a }\end{array}$ & 2011 \\
\hline 9 & $\begin{array}{c}\text { PT. Insani } \\
\text { Bara } \\
\text { Perkasa }\end{array}$ & $\begin{array}{l}\text { Wilson } \\
\text { (17) }\end{array}$ & $\begin{array}{c}\text { KM.9, RT } \\
\text { 18, Desa } \\
\text { Purwajaya, } \\
\text { Kec.Loa } \\
\text { janan }\end{array}$ & $\begin{array}{c}15 \mathrm{Mei} \\
2016\end{array}$ \\
\hline 10 & $\begin{array}{c}\text { PT. Hymco } \\
\text { Coal }\end{array}$ & $\begin{array}{c}\text { Miftahul } \\
\text { Janah } \\
\text { (10) }\end{array}$ & $\begin{array}{c}\text { Sungai } \\
\text { Kerbau } \\
\text { Kec. } \\
\text { Sambutan } \\
\end{array}$ & 13 Juli 2011 \\
\hline 11 & $\begin{array}{c}\text { PT. Hymco } \\
\text { Coal }\end{array}$ & $\begin{array}{c}\text { Junaidi } \\
\text { (13) }\end{array}$ & $\begin{array}{c}\text { Sungai } \\
\text { Kerbau } \\
\text { Kec. } \\
\text { Sambutan }\end{array}$ & 13 Juli 2011 \\
\hline 12 & $\begin{array}{c}\text { PT. Hymco } \\
\text { Coal }\end{array}$ & $\underset{\mathrm{ni}}{\text { Ramadha }}$ & $\begin{array}{c}\text { Sungai } \\
\text { Kerbau } \\
\text { Kec. } \\
\text { Sambutan }\end{array}$ & 13 Juli 2011 \\
\hline 13 & $\begin{array}{l}\text { PT. Panca } \\
\text { Prima Mining }\end{array}$ & $\begin{array}{c}\text { Dede } \\
\text { Rahmad } \\
\text { (Eza) (6) }\end{array}$ & $\begin{array}{c}\text { Sambutan } \\
\text { Idaman } \\
\text { Permai } \\
\text { Pelita } 2 \\
\end{array}$ & $\begin{array}{c}24 \\
\text { Desember } \\
2011\end{array}$ \\
\hline 14 & $\begin{array}{l}\text { PT. Panca } \\
\text { Prima } \\
\text { Mining/PD } \\
\text { PAU }\end{array}$ & $\begin{array}{c}\text { Emaliya } \\
\text { Raya } \\
\text { Dinata } \\
\text { (Ema) } \\
(6)\end{array}$ & $\begin{array}{c}\text { Sambutan } \\
\text { Idaman } \\
\text { Permai } \\
\text { Pelita } 2 \\
\text { Samarinda }\end{array}$ & $\begin{array}{c}24 \\
\text { Desember } \\
2011\end{array}$ \\
\hline 15 & $\begin{array}{l}\text { PT. Insani } \\
\text { Bara } \\
\text { Perkasa }\end{array}$ & $\begin{array}{c}\text { Maulana } \\
\text { Mahendr } \\
\text { a (11) }\end{array}$ & $\begin{array}{c}\text { Blok B } \\
\text { RT.20 } \\
\text { Simpang } \\
\text { Pasir } \\
\text { Palaran } \\
\end{array}$ & $\begin{array}{c}25 \\
\text { Desember } \\
2012\end{array}$ \\
\hline 16 & $\begin{array}{c}\text { Tak } \\
\text { Teridentifika } \\
\text { si }\end{array}$ & $\begin{array}{c}\text { M. } \\
\text { Shendy } \\
(8)\end{array}$ & $\begin{array}{c}\text { Sambutan } \\
\text { Pelita 4, } \\
\text { Handil } \\
\text { Kopi, Blok } \\
\text { L No.4 }\end{array}$ & $\begin{array}{l}14 \text { Maret } \\
2013\end{array}$ \\
\hline 17 & $\begin{array}{c}\text { PT. Energi } \\
\text { Cahaya } \\
\text { Industritama }\end{array}$ & $\begin{array}{c}\text { Nadia } \\
\text { Zaskia } \\
\text { Putri (10) }\end{array}$ & $\begin{array}{c}\text { Kel. Rawa } \\
\text { Makmur } \\
\text { Kec. } \\
\text { Palaran }\end{array}$ & 8-Apr-14 \\
\hline 18 & $\begin{array}{l}\text { PT. Graha } \\
\text { Benua Etam }\end{array}$ & $\begin{array}{c}\text { M.Raiha } \\
\text { n Saputra } \\
(10)\end{array}$ & $\begin{array}{c}\text { Sempaja } \\
\text { Samarinda }\end{array}$ & $\begin{array}{c}22 \\
\text { Desember } \\
2014\end{array}$ \\
\hline
\end{tabular}

${ }^{1}$ Salim HS, 2005, Hukum Pertambangan di Indonesia, Raja Grafindo Persada ; Jakarta, hlm 5-6.

2 Database Jatam Kalimantan Timur 20112016. 


\begin{tabular}{|c|c|c|c|c|}
\hline 19 & $\begin{array}{c}\text { PT. Cahaya } \\
\text { Energi } \\
\text { Mandiri }\end{array}$ & $\begin{array}{c}\text { Ardi Bin } \\
\text { Hasyim } \\
\text { (11) }\end{array}$ & $\begin{array}{l}\text { Sambutan } \\
\text { Samarinda }\end{array}$ & $\begin{array}{c}23 \mathrm{Mei} \\
2015\end{array}$ \\
\hline 20 & $\begin{array}{l}\text { PT. Lanna } \\
\text { Harita }\end{array}$ & $\begin{array}{c}\text { M. } \\
\text { Yusuf } \\
\text { Subhan } \\
(11)\end{array}$ & $\begin{array}{c}\text { Sungai } \\
\text { Siring } \\
\text { Samarinda }\end{array}$ & $\begin{array}{l}24 \text { Agustus } \\
2015\end{array}$ \\
\hline 21 & $\begin{array}{l}\text { PT. Transisi } \\
\text { Energi }\end{array}$ & $\begin{array}{c}\text { Aprillia } \\
\text { Wulanda } \\
\text { ri (12) }\end{array}$ & $\begin{array}{l}\text { Lok Bahu } \\
\text { Samarinda }\end{array}$ & $\begin{array}{c}18 \\
\text { Nopember } \\
2015\end{array}$ \\
\hline 22 & $\begin{array}{l}\text { CV. Atap Tri } \\
\text { Utama }\end{array}$ & $\begin{array}{c}\text { Koko } \\
\text { Dwi } \\
\text { Handoko } \\
(16) \\
\end{array}$ & $\begin{array}{c}\text { Bantuas } \\
\text { Palaran } \\
\text { Samarinda }\end{array}$ & $\begin{array}{c}08 \\
\text { Desember } \\
2015\end{array}$ \\
\hline 23 & $\begin{array}{c}\text { CV. Panca } \\
\text { Bara } \\
\text { Sejahtera }\end{array}$ & $\begin{array}{c}\text { Kusmaya } \\
\text { di (22) }\end{array}$ & $\begin{array}{c}\text { Samarinda } \\
\text { Ulu }\end{array}$ & $\begin{array}{l}03 \text { Mei } \\
2016\end{array}$ \\
\hline 24 & $\begin{array}{l}\text { PT. Insani } \\
\text { Bara } \\
\text { Perkasa }\end{array}$ & $\begin{array}{c}\text { M. } \\
\text { Arham } \\
(5)\end{array}$ & $\begin{array}{c}\text { Palaran, } \\
\text { Samarinda }\end{array}$ & $\begin{array}{c}06 \mathrm{Mei} \\
2016\end{array}$ \\
\hline 25 & $\begin{array}{c}\text { PT. Bumi } \\
\text { Energi } \\
\text { Kaltim }\end{array}$ & $\begin{array}{l}\text { Agus } \\
\text { Irawan } \\
(20)\end{array}$ & $\begin{array}{c}\text { Buluminung, } \\
\text { Penajam } \\
\text { Paser Utara }\end{array}$ & $\begin{array}{l}12 \text { Februari } \\
2016\end{array}$ \\
\hline
\end{tabular}

Sumber : Data base Jatam Kaltim tahun 2015

Meskipun telah banyak menelan korban anak-anak tenggelam di lubang eks tambang batubara yang sampai juni berjumlah 25 (dua puluh lima) orang sebagaimana data tersebut diatas, namun dalam kenyataannya setiap peristiwa tenggelamnya anak dilubang tambang tidak pernah sekalipun terselesaikan secara tuntas pada jalur hukumnya. Lemahnya pembelaan dan penuntasan kasus demi kasus yang ada berkaitan dengan lubang tambang tersebut dikarenakan oleh banyak pihak yang tidak pernah selesai mulai dari kepolisian, pihak perusahaan, hingga pada pemerintah kota, dan pemerintah pusat.

Secara hukum kasus tanggung jawab terhadap hilangnya nyawa orang di lubang tambang batubara pertanggungjawabannya bukan satu orang, tetapi ada beberapa pihak yang bertanggungjawab.

\section{B. Permasalahan}

Berdasar pada latar belakang diatas maka permasalahan yang diangkat dalam penelitian ini sebagai berikut :

1. Apakah Hilangnya Nyawa Orang Di Lubang Tambang Batubara Memenuhi Unsur-unsur Tindak Pidana.(Studi kasus PT. Cahaya Energi Mandiri (CEM), Kelurahan Sambutan Kecamatan Samarinda Ilir) ?

2. Bagaimana Tanggung jawab Hukum terhadap Hilangnya Nyawa Orang Di Lubang Tambang Batubara Ditinjau Dari Perspektif Hukum Pidana. (Studi kasus PT. Cahaya Energi Mandiri (CEM),Kelurahan Sambutan

Kecamatan Samarinda Ilir)?

\section{Tujuan dan Manfaat Penelitian}

Adapun tujuan dari penelitian ini adalah Untuk mengetahui dan menganalisis Tanggung Jawab Hukum Terhadap Hilangnya Nyawa Orang Di Lubang Tambang Batubara Ditinjau Dari Perspektif Hukum Pidana, dan Untuk mengetahui dan menganalisa unsur-unsur tindak pidana dikaitkan dengan bidang pertambangan batubara.

Penelitian ini diharapkan bermanfaat baik Secara Teoritis yaitu Penelitian ini di harapkan memberikan pemahaman terhadap perkembangan hukum di Indonesia, khususnya mengenai Tanggung Jawab Hukum Terhadap Hilangnya Nyawa Orang Di Lubang Tambang Batubara Ditinjau Dari Perspektif Hukum pidana, dan Penelitian ini diharapkan dapat menambah bahan wawasan ilmu hukum dalam perkembangan hukum pidana di Indonesia khususnya dibidang pertambangan batubara.

Secara Praktis Penelitian ini di harapkan dapat memberikan pengetahuan untuk penegakan hukum dalam bidang pertambangan batubara, dan Penelitian ini diharapkan dapat memberikan solusi bagi penegak hukum terkait dengan masalah pertanggungjawaban pidana. 


\section{METODE PENELITIAN}

Jenis Penelitian yang digunakan penulis adalah Penelitian Hukum normatifempiris yaitu ${ }^{3}$ Penggabungan antara pendekatan hukum normatif dengan adanya penambahan dari berbagai unsur-unsur empiris.

Penelitian Hukum Normatif atau penelitian doktinal yaitu penelitian perpustakaan atau studi dokumen, penelitian ini ditujukan hanya pada peraturan yang tertulis atau bahan hukum yang lain. Penelitian Hukum empiris penelitian lapangan berupa Pendekatan kasus, Pendekatan Perundang-undangan, wawancara, dan studi-studi empiris untuk menemukan teori-teori mengenai proses terjadinya dan mengenai proses bekerjanya hukum didalam masyarakat. ${ }^{4}$

Jenis penelitian ini dilakukan dengan mengadakan penelitian langsung dilapangan dengan tujuan untuk mengumpulkan data yang objektif yang disebut dengan data primer.Metode penelitian dalam penelitian ini diharapkan mampu memahami dan mengkaji tentang Tanggung Jawab Hukum Terhadap Hilangnya Nyawa Orang Di lubang Tambang Batubara Ditinjau Dari Perspektif Hukum Pidana.

Sumber Data yang digunakan dalam penelitian hukum ini bersumber dari data primer dan sekunder.

a. Data primer adalah kata - kata dan tindakan orang yang diamati atau diwawancarai. Pencatatan sumber data utama melalui pengamatan atau observasi dan wawancara merupakan hasil usaha gabungan dari kegiatan melihat, mendengar, dan bertanya yang dilakukan secara sadar, terarah, dan senantiasa bertujuan untuk memperoleh informasi yang diperlukan, yang diperoleh secara langsung dari responden yaitu terkait dengan Tanggung Jawab Hukum Terhadap

3 Suratman dan Philip, 2012, Metode Penelitian Hukum, Alfabeta; Malang, hlm.51-53.

4 Bambang Sunggono, 2003, Metode Penelitian Hukum, Raja Grafindo Persada; Jakarta, hlm. 43.
Hilangnya Nyawa Orang Di Lubang Tambang Batubara Ditinjau Dari Perspekti Hukum Pidana. (Studi Kasus PT. Cahaya Energi Mandiri (CEM), Kelurahan sambutan kecamatan samarinda ilir )

b. Data sekunder yang berfungsi sebagai pelengkap atau pendukung data primer. Data ini bersumber dari literatur yaitu peraturan perundang-Undangan, Dokumen resmi yang berhubungan dengan Tanggung Jawab Hukum Terhadap Hilangnya Nyawa Orang Di Lubang Tambang Batubara Di Tinjau Dari Perspekti Hukum Pidana.(Studi Kasus PT. Cahaya Energi Mandiri (CEM), Kelurahan Sambutan kecamatan samarinda Ilir).

Metode pengumpulan data merupakan salah satu faktor yang paling penting dalam menentukan berhasil atau tidaknya suatu penelitian. Jadi metode penelitian ini harus diperhatikan kesesuaiannya dengan jenis data, jika tidak sesuai maka akan mengakibatkan masalah yang diteliti tidak dapat diungkap dengan baik. Kualitas suatu hasil penelitian sangat dipengaruhi oleh kualitas dari metode pengumpulan data serta instrument yang digunakan dalam melakukan penelitian oleh karenanya untuk memperoleh data yang diinginkan, maka dalam pengumpulannya untuk memperoleh data primer dan data sekunder adalah sebagai berikut:

\section{a. Data Primer}

Wawancara Kepada narasumber dengan cara melaksanakan tanya jawab dengan responden guna mendapatkan keterangan secara langsung kepada pihak masyarakat, perusahaan dan pihak terkait. Adapun teknik wawancara dalam penelitian ini adalah dengan menggunakan Interview guide (panduan wawancara). ${ }^{5}$ Teknik ini digunakan untuk memperoleh data dari informasi-informasi yang mempunyai relevansi dengan masalah yang diangkat dalam penelitian ini.

5 Soerjono soekanto, 2012, Pengantar Penelitian Hukum, UI Press; Jakarta, hlm. 8. 
b. Data Sekunder

1) Studi kepustakaan (bilbliography study) yaitu dengan menggunakan Perundang - undangan dan buku-buku yang terkait dengaan masalah yang akan diteliti dalam penelitian ini, dan melakukan pengumpulan data melalui perundang - undangan yang terkait dengan masalah yang diteliti juga melalui internet, majalah dan melalui kamus bahasa, dan kamus - kamus lain yang berhubungan dengan permasalahan yang akan diteliti dalam penelitian ini.

2) Studi dokumentasi (document study) adalah dengan mengkaji berbagai dokumen-dokumen resmi pemerintah yang berupa peraturan-peraturan Bupati dan arsip-arsip yang dapat menunjang penelitian, tentunya yang berhubungan dengan permasalahan dalam penelitian ini serta terkait dengan Tanggung Jawab Hukum Terhadap Hilangnya Nyawa Orang Di Lubang Tambang Batubara Ditinjau Dari Perspektif Hukum Pidana.

Analisis data dalam Penelitian ini dengan cara data yang diperoleh selama penelitian ini akan dianalisis secara kualitatif.Penyusunan data melalui tahapan Kualitatif, yaitu, pertama, menemukan makna dan konsep - konsep yang terkandung dalam bahan Hukum. Kedua mengelompokan konsep-konsep yang sejenis atau berkaitan (kategorisasi). Ketiga Menemukan hubungan diantara kategorikategori dalam penelitian. Keempat hubungan diantara kategori akan dianalisis menurut aspek Tanggung Jawab, Kemampuan Bertanggung Jawab Dalam hukum Pidana, Penanggung jawab Subjek hukum.

\section{HASIL PENELITIAN DAN PEMBAHASAN}

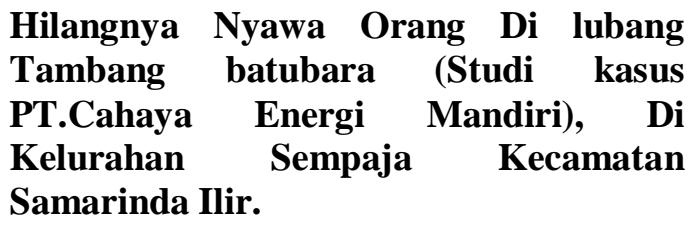

Berdasarkan wawancara pada tanggal 09 Februari 2017 dengan kanit Reskrim Bapak Purwanto dan Aiptu Bambang Riono bahwa memang benar ada kasus anak yang jatuh dan meninggal di lubang tambang batubara areal kosesi PT. Cahaya Energi mandiri dengan identitas korban yang meninggal sebagai berikut: Nama : Ardi, Umur : 13 (Tiga belas tahun), Suku: Makasar/Indonesia, Kejadian: 25 Mei 2017, Nama Ayah: Hasbullah binti Syamsudin, Nama ibu: Nuraini Binti Talangka, Nama KTT: F.Eka Wijayanti Binti Hery Susanto.

Sebelum terjadi insiden hilangnya nyawa orang di lubang tambang, korban ini sering masuk keareal tambang kemudian KTT mengantarkan korban keluar tambang. Hal ini terjadi berulang kali, sampai dengan ditemukannya korban ini mengapung di lubang tambang yang berisi air.

Pihak kepolisian langsung ketempat kejadian perkara (TKP) dan memeriksa mulai dari karyawan sampai dengan menejer PT. Cahaya Energi Mandiri. Kendala yang dihadapi kepolisian adalah bahwa orang tua tidak mau kalau anaknya divisum. Hingga saat ini kasus hilangnya nyawa orang dilubang tambang studi kasus di PT. Cahaya energi Mandiri masih dalam proses penyidikan.

\section{A. Hilangnya Nyawa Orang Di Lubang Tambang Batubara memenuhi Unsur-Unsur Hukum Pidana. \\ 1). Pertangung jawaban Pidana terhadap Pemegang IUP . \\ Untuk mengetahui hilangnya nyawa} orang di lubang tambang batubara milik PT. Cahaya Energi Mandiri, maka rumusan ketentuan pidana yang relevan adalah yang berkaitan dengan peraturan perundangundangan mengenai hilangnya nyawa orang lain. Meskipun permasalahan yang timbul atas Hilangnya Nyawa Orang Di Lubang Tambang Batubara, pada dasarnya dapat ditinjau dari berbagai aspek, termasuk aspek administrasi, perdata maupun pidana. Jika dilihat dari hilangnya nyawa orang lain di lubang tambang PT. Cahaya Energi Mandiri (CEM), maka aspek korporasi sebagai subjek hukum yang menguasai dan bertangungjawab atas Tempat Kejadian Perkara atau tempat ditemukannya Korban 
serta orang tua korban sebagai subyek hukum.

Terdapat celah untuk diberikan sanksi pidana kejahatan terhadap nyawa yang dilakukan tidak dengan sengaja (culpose misjdrijven) yang dimuat dalam XXI khususnya Pasal 359 KUHP salah satu unsurnya adalah barang siapa yang ditujukan pada pelaku Unsur (bestandeel) ini menunjuk kepada pelaku/subyek tindak pidana, yaitu orang dan korporasi, yaitu orang pribadi (naturlijke persoon) dan korporasi sebagai badan hukum (recht persoon).

Sedangkan menurut Sudikno Mertokusumo Subyek hukum (subjectum juris) adalah segala sesuatu yang dapat memperoleh, mempunyai atau menyandang hak dan kewajiban dari hukum, yang terdiri dari orang (natuurlijkepersoon) badan hukum (rechtspersoon). Untuk itu yang dimaksud dalam unsur barang siapa dapat berupa perorangan maupun badan hukum. Terkait Hilangnya Nyawa Orang Di Lubang Tambang Batubara, pada penelitian penulis, diperoleh data sebegai berikut:

Pada tangggal 25 mei 2015, di temukan seorang anak yang tewas di lubang tambang yang di penuhi dengan kubangan air oleh warga setempat, pada saat kejadian menurut orang tua korban Nuraini Binti Talangka sebelumnya korban sempat menghilang selama 3 (Tiga) hari kemudian tiba-tiba mendapat kabar bahwa telah ditemukan seorang anak di lubang tambang yang telah mengapung, adapun lubang tambang tempat di temukannya korban berdasarkan keterangan dari orang tua korban dan pihak Jaringan Advokasi Tambang adalah termasuk dalam wilayah konsesi IUP Operasi Produksi PT. C.E.M yang sebelumnya juga tidak terdapat rambu-rambu peringatan keselamatan.

Terkait permasalahan ini hingga sampai dengan saat ini belum ada yang ditetapkan siapa tersangka atas peristiwa/kejadian ini dan menurut informasi pada saat wawancara secara langsung antara penulis dengan pihak Kanit Polsek Samarinda Ilir bapak Ipda Purwanto, mengatakan bahwa perkara ini hingga sampai dengan sekarang masih dalam lidik atau penyelidikan pihak Kepolisian.
Bahwa dari hasil penelitian penulis terdapat fakta adanya hilangnya nyawa orang di lubang tambang, maka tentunya permasalahan dalam kasus tersebut dapat dilakukan penyelidikan maupun penyidikan terkait dugaan tindak pidana terhadap hilangnya nyawa orang. Jika dilihat dari peristiwa hilangnya nyawa orang tersebut yang ditemukan dilubang tambang, pengkajian mengenai petanggungjawaban pidananya baik terhadap PT. Cahaya Energi Mandiri (C.E.M) selaku pemegang IUP dan orang tua maupun pihak yang bertanggung jawab dalam pengawasan pengelolaan lingkungan hidup atau pemerintah, maka dugaan atas peristiwa tersebut adalah Pasal 359 KUHP menyatakan, Barangsiapa karena kelalaiannya menyebabkan matinya orang dihukum penjara selama-lamanya lima tahun atau kurungan selama-lamanya satu tahun. Dengan demikian Unsur -unsur dari rumusan pasal 359 KHUP tersebut adalah: ${ }^{6}$

1. Adanya unsur kelalaian (culpa)

2. Adanya wujud perbuatan tertentu

3. Adanya kematian orang lain

4. Adanya hubungan kausal antara wujud perbuatan dengan kematian orang lain itu.

Dalam hukum pidana, kelalaian, kesalahan, kurang hati-hati, atau kealpaan disebut dengan culpa. Dalam M.v.T (Memorie van Toelichting) dijelaskan bahwa dalam hal kealpaan, pada diri pelaku terdapat:

a. Kekurangan pemikiran (penggunaan akal) yang diperlukan.

b. Kekurangan pengetahuan (ilmu) yang diperlukan.

c. Kekurangan kebijaksanaan (beleid) yang diperlukan.

Kelalaian sendiri di artikan menurut Wirjono Prodjodikoro, berpendapat bahwa arti culpa adalah kesalahan pada umumnya, tetapi dalam ilmu pengetahuan hukum mempunyai arti teknis, yaitu suatu macam kesalahan si

6 Adam Chazawi, 2004, Kejahatan Terhadap Tubuh Dan Nyawa, PT. Raja Grafindo Persada; Jakarta, hlm. 125. 
pelaku tindak pidana yang tidak seberat seperti kesengajaan, yaitu kurang berhatihati sehingga akibat yang tidak disengaja terjadi. ${ }^{7}$ Jan Remmelink pernah mengatakan bahwa pada intinya, culpa mencakup kurang cermat berpikir, kurang pengetahuan, atau bertindak kurang terarah. Menurut Jan Remmelink, ihwal culpa di sini jelas merujuk pada kemampuan psikis seseorang dan karena itu dapat dikatakan bahwa culpa berarti tidak atau kurang menduga secara nyata (terlebih dahulu kemungkinan munculnya) akibat fatal dari tindakan orang tersebut - padahal itu mudah dilakukan dan karena itu seharusnya dilakukan. ${ }^{8}$ Hal serupa juga dikatakan oleh Wirjono Prodjodikoro, yaitu bahwa menurut para penulis Belanda, yang dimaksudkan dengan culpa dalam pasalpasal KUHP adalah kesalahan yang agak berat. Istilah yang mereka pergunakan adalah grove schuld (kesalahan besar). Meskipun ukuran grove schuld ini belum tegas seperti kesengajaan, namun dengan istilah grove schuld ini sudah ada sekedar ancar-ancar bahwa tidak masuk culpa apabila seorang pelaku tidak perlu sangat berhati-hati untuk bebas dari hukuman. Lebih lanjut, dikatakan bahwa untuk culpa ini harus diambil sebagai ukuran bagaimana kebanyakan orang dalam masyarakat bertindak dalam keadaan yang in concreto terjadi. Jadi, tidaklah dipergunakan sebagai ukuran seorang yang selalu sangat berhatihati, dan juga tidak seorang yang selalu serampangan dalam tindak tanduknya. ${ }^{9}$ Dalam kaitannya dengan peristiwa hilangnya nyawa orang di dalam lubang tambang yang berisi genangan air di wilayah Konsesi IUP PT. CEM karena pihak perusahaan tidak menutup bekas galian yang menjadi lubang, maka hal ini dapat dikatakan sebagai perbuatan kelalaian / Kealpaan akibat, karena pemegang IUP telah berbuat lain dari apa yang seharusnya diperbuat menurut hukum tertulis.

7 Wirjono Prodjodikoro, 2003, Asas-Asas Hukum Pidana di Indonesia, PT Refika Aditama; Jakarta, hlm. 72.

8 Jan Remmelink, 2003, Hukum Pidana, PT

Gramedia Pustaka Utama; Jakarta, hlm. 177

${ }^{9}$ Wirjono Prodjodikoro, Op.cit, hal. 73
Sehingga sebenarnya ia telah melakukan suatu perbuatan (termasuk tidak berbuat) yang melawan hukum, dalam hal ini kegiatan pertambangan harus dilakukan secara benar dan terarah oleh perusahaan pertambangan sebagaimana yang tertuang dalam Undang-Undang Nomor 4 Tahun 2009 Tentang Pertambangan Mineral dan Batubara sesuai pasal 96 huruf $\mathrm{b}$ dan $\mathrm{c}$ tentang Pertambangan Mineral dan Batubara adalah melakukan keselamatan operasi pertambangan, serta reklamasi lahan dan hutan pasca pertambangan.

Kewajiban ini kemudian juga telah diatur dalam Peraturan Pemerintah No. 78 tahun 2010 tentang Reklamasi dan Pasca Tambang pasal 2 ayat 1 yang menyebutkan bahwa pemegang IUP Eksplorasi dan IUPK Eksplorasi wajib melaksanakan reklamasi, dan pasal 2 ayat 2 yang menyebutkan bahwa IUP Operasi Produksi dan IUPK Operasi Produksi wajib melaksanakan reklamasi dan pasca tambang.Yang kemudian dalam jangka waktu 30 hari harus menutup areal tambang yang tidak beroperasi atau melakukan sistem pertambangan dengan metode backfilling sebagaimana Peraturan Daerah Kota Samarinda Nomor 12 Tahun 2013 tentang Pertambangan Mineral dan Batu Bara dalam Wilayah Kota Samarinda.

Pada Pasal 34 disebutkan, "Dalam rangka memberi jaminan keselamatan dan kelestarian lingkungan, serta upaya menekan korban nyawa manusia, maka sistem pertambangan dengan metode backfilling (sistem buka tutup) wajib dilakukan oleh setiap pemegang IUP/ IUPK dan IPR. Dalam melakukan aktivitas pertambangan perusahaan juga wajib memasang rambu-rambu dan melakukan pengawasan secara ketat terhadap wilayah operasi pertambangan sebagai upaya pemenuhan terhadap ketentuan pasal 96 huruf $\mathrm{b}$ Undang-Undang Nomor. 4 tahun 2009 Tentang Pertambangan Mineral dan Batubara yakni kewajiban melakukan keselamatan operasi pertambangan. 
Dalam teori ajaran sifat melawan hukum, melawan hukum diartikan sebagai bertentangan dengan hukum, bukan saja terkait dengan hak orang lain (hukum subjektif), melainkan juga mencakup Hukum Perdata atau Hukum Administrasi Negara, seperti yang pernah dikemukan Simons. Membiarkan lubang tambang tetap terbuka tanpa melakukan penutupan bekas galian atau tidak melakukan reklamasi atau pasca tambang atau tidak melakukan metode-metode pertambangan sebagaimana yang telah ditetapkan dalam peraturan yang telah memberikan batasan-batasan teknis.

Pertambangan yang benar dan terarah adalah suatu kesalahan yang tentunya dapat di mintakan pertanggungjawaban pidananya karena didalam ketentuan pasal 4 Peraturan Mahkamah Agung Republik Indonesia Nomor 13 Tahun 2016 tentang tata cara penangan perkara tindak pidana oleh korporasi.

Secara expressis verbis telah menegaskan korporasi dapat dimintakan pertanggungjawaban pidana apabila terdapat keadaan-keadaan bahwasanya Korporasi membiarkan terjadinya tindak pidana atau korporasi tidak melakukan langkah-langkah yang diperlukan untuk melakukan pencegahan, mencegah dampak yang lebih besar dan memastikan kepatuhan terhadap ketentuan hukum yang berlaku guna menghindari terjadinya tindak pidana. Dengan demikian apabila perusahaan yang tidak melakukan Penutupan bekas galian atau tidak melakukan reklamasi atau pasca tambang atau tidak melakukan metodemetode pertambangan dan membiarkan lubang tambang tetap terbuka tanpa melakukan kegiatan reklamasi atau pasca tambang dan metode-metode pertambangan sebagaimana yang telah ditetapkan dalam undang-undang tentunya merupakan kesalahan karena tidak berbuat sebagaimana seharusnya. Sehingga unsur kelalaian dalam rumusan pasal 359 KUHP yakni Adanya unsur kelalaian (culpa) dan Adanya wujud perbuatan tertentu telah ada dan nyata.
Hilangnya nyawa orang di lubang tambang yang di temukan dilubang tambang hingga sampai dengan saat ini masih belum ditemukan adanya visum atau hasil aoutopsi yang menujukkan bahwa kematian korban sebagai akibat yang berkaitan langusng dari perbuatan kelalaian perusahaan. Sedangkan dalam teori conditio sine qua non atau yang juga dikenal teori mutlak yang menyatakan bahwa musabab adalah setiap syarat yang tidak dapat dihilangkan untuk timbulnya akibat. Dimana teori ini juga dikemukakan oleh Von Buri, Ketua Mahkamah Agung Jerman yang menyatakan pendapatnya, bahwa syarat (bedingung) Identik dengan musabab dan oleh karena itu setiap syarat mempunyai nilai yang sama (equivalent). ${ }^{10}$ Dalam fakta yang terjadi telah terdapat dan ditemukan anak yang mati di dalam lubang tambang, untuk itu apabila kematian korban dikarenakan perbuatan pemegan IUP yang memiliki kewajiban untuk menutup lubang tambang akan tetapi tidak berbuat untuk menutup lubang tambang tersebut sesuai dengan peraturan yang berlaku sebagaimana hukum yang tertulis.

Unsur Adanya hubungan kausal antara wujud perbuatan dengan kematian orang lain itu harus di pertanggung jawabkan oleh pihak pemegang IUP karena adanya kesalahan dari pemegang IUP yang tidak melakukan langkah-langkah yang diperlukan untuk melakukan pencegahan. Mencegah dampak yang lebih besar dan memastikan kepatuhan terhadap ketentuan hukum yang berlaku guna menghindari terjadinya tindak pidana.

\section{2). Pertanggung jawababan Pidana Terhadap Orang Tua.}

untuk menempatkan orang tua korban sebagai pelaku perbuatan yang turut bertanggung jawab pula atas kematian anaknya yang meninggal di lubang tambang PT. Cahaya Energi Mandiri tentunya perlu ditinjau terlebih dahulu mengenai kewajiban-kewajiban orang tua korban terhadap tempat kejadian perkara dalam hal

${ }^{10}$ JM Van Bemmele En W.F.C Van Hattum, Op.Cit, hal. 173 
ini lubang tambang tempat ditemukannya korban yang merupakan obyek peristiwa.

Dalam Undang - undang perlindungan anak, Orang tua berkewajiban dan bertanggung jawab untuk:

a) Mengasuh, memelihara, mendidik, dan melindungi Anak;

b) Menumbuh kembangkan Anak sesuai dengan kemampuan, bakat, dan minatnya;

c) Mencegah terjadinya perkawinan pada usia Anak; dan

d) Memberikan pendidikan karakter dan penanaman nilai budi pekerti pada Anak.

Kewajiban-kewajiban tersebut, telah secara tegas tertuang didalam UndangUndang Republik Indonesia Nomor 35 Tahun 2014 tentang Perubahan Atas Undang-Undang Nomor 23 Tahun 2002 tentang Perlindungan Anak. Akan tetapi apa yang dimaksudkan dalam kewajibankewajiban tersebut tidaklah termasuk kewajiban mengawasi anak-anak diwilayah atau dalam object peristiwa atau ditempat kejadian perkara (TKP).

Sebaliknya kewajiban-kewajiban pada object peristiwa atau di tempat kejadian perkara adalah pemegang IUP/IUPK/IPR dan kewajiban pengawasannya oleh pemerintah, sebagaimana yang telah ditetapkan melalui Undang-Undang Nomor 4 tahun 2009 Tentang Pertambangan Mineral dan Batubara, Undang-Undang Republik Indonesia Nomor 32 Tahun 2009 tentang Perlindungan Dan Pengelolaan Lingkungan Hidup Peraturan Pemerintah No. 78 tahun 2010 tentang Reklamasi dan Pasca Tambang dan Peraturan Daerah Kota Samarinda Nomor 12 Tahun 2013 tentang Pertambangan Mineral dan Batu Bara dalam Wilayah Kota Samarinda.

Sedangkan menurut asas Geen straf zonder schuld, tiada pidana tanpa kesalahan, maka untuk dapat mempertanggungjwabkan suatu perbuatan harus ada kesalahan pada diri pelaku. Untuk itu orang tua korban tidak dapat disangkakan sebagai pelaku perbuatan pidana. Karena kewajiban untuk melakukan keselamatan operasi pertambangan, serta reklamasi lahan dan hutan pasca pertambangan maupun memberikan jaminan keselamatan dan kelestarian lingkungan serta upaya menekan korban nyawa manusia di tempat kejadian perkara (TKP) adalah kewajiban mutlak setiap pemegang IUP/ IUPK dan IPR, dan pengawasannya ada pada Pemerintah sesuai Dalam pasal 71 Ayat (1) dan pasal 72 Undang-Undang Republik Indonesia Nomor 32 Tahun 2009 tentang Perlindungan Dan Pengelolaan Lingkungan Hidup.

Perlindungan dan Pengelolaan Lingkungan Hidup telah memberikan uraian bahwa siapa saja pejabat yang diberi wewenang atributif melakukan pengawasan yakni Menteri, gubernur, atau bupati/walikota sesuai dengan kewenangannya, wajib melakukan pengawasan terhadap ketaatan penanggung jawab usaha dan/atau kegiatan atas ketentuan yang ditetapkan dalam peraturan perundang-undangan di bidang perlindungan dan pengelolaan lingkungan hidup.

\section{3) Pertangungjawaban Terhadap Pemerintah.}

Undang-Undang Nomor 32 Tahun 2009 memperkenalkan ancaman hukuman minimum di samping maksimum, perluasan alat bukti, pemidanaan bagi nelanogaran Pengelolaan Lingkunge 73 lidup, keterpaduan penegakan hukv $\quad \mathrm{l}$, dan pengaturan memperhatikan azas ultimum remedium yang mewajibkan penerapan penegakan hukum pidana sebagai upaya terakhir setelah penerapan penegakan hukum administrasi dianggap tidak berhasil.

Penerapan asas ultimum remedium ini hanya berlaku bagi tindak pidana formil tertentu. Menyangkut ultimum remedium Alvi Syahrin dalam buku "Beberapa Isu Hukum Lingkungan Kepidanaan" mengemukakan bahwa :

Hukum pidana dipandang sebagai ultimum remedium artinya hukum pidana hendaknya dipandang sebagai upaya yang terakhir dalam memperbaiki kelakukan manusia. 
Perkataan ultimum remedium ini pertama sekali dipergunakan oleh Menteri Kehakiman Belanda yaitu Mr Modderman dalam menjawab pertanyaan Mr Mackay seorang anggota parlemen Belanda mengenai dasar hukum perlunya penjatuhan hukuman bagi seseorang yang telah melakukan suatu pelanggaran hukum.

Modderman menyatakan bahwa yang dapat dihukum itu pertama adalah pelanggaranhukum. Ini merupakan conditio sine qua non (syarat yang tidak boleh tidak ada). Kedua, yang dapat dihukum itu adalah pelanggaran hukum, yang menurut pengalaman tidaklah dapat ditiadakan dengan cara lain.

Hukuman itu hendaknya merupakan suatu upaya terakhir (ultimum remedium). Memang terhadap setiap ancaman pidana ada keberatannya. Setiap orang yang berpikir sehat akan mengerti hal tersebut tanpa penjelasan lebih lanjut. Ini tidak berarti bahwa ancaman pidana akan ditiadakan, tetapi harus mempertimbangkan keuntungan dan kerugian ancaman pidana benar-benar menjadi upaya penyembuhan serta harus menjaga jangan sampai membuat penyakitnya lebih parah". ${ }^{11}$ Penentuan kejahatan lingkungan hidup harus dimulai dari penempatan kejahatan lingkungan hidup di dalam undang-undang, yang lazim dikatakan sebagai Kriminalisasi. Sudarto menyatakan bahwa mengenai masalah kriminalisasi harus memperhatikan hal-hal sebagai berikut: ${ }^{12}$

a. Penggunaan hukum pidana harus memperhatikan tujuan pembangunan nasional, yaitu mewujudkan masyarakat adil makmur secara merata baik materil dan seprituil berdasarkan Pancasila, sehubungan dengan ini maka penggunaan hukum pidana bertujuan untuk menanggulangi kejahatan dan mengadakan terhadap tindakan penanggulangan itu sendiri, demi keselamatan dan pengayoman masyarakat.

11 Alvi Syahrin, 2009 Beberapa Isu Hukum Lingkungan Kepidanaan, Jakarta: PT. Sofmedia, hlm. 9

12 Sudarto, Hukum dan Hukum Pidana, Bandung: Alumni, 1981, hlm. 44-47 b. Perbuatan yang diusahakan untuk dicegah atau ditanggulangi dengan hukum pidana harus merupakan perbuatan yang tidak dikehendaki yaitu perbuatan yang mendatangkan kerugiaan (materiil dan atau spritual) atas warga masyarakat.

c. Penggunaan hukum pidana harus memperhatikan kapasitas atau kemampuan daya kerja dari badanbadan penegak hukum yaitu jangan sampai ada kelampauan beban tugas (overbelasting)

Terkait hilangnya nyawa orang di lubang tambang batubara diareal konsesi PT. Cahaya Energi Mandiri ditinjau dari Undang-undang Perlindungan dan Pengelolaan Lingkungan Hidup, maka ketentuan pidana yang relevan untuk diterapkan apabila penerapan penegakan hukum administrasi dianggap tidak herhasil dan guna menghindari sel 76 ncegah perbuatan yang mendatangl rugiaan (materiil dan spritual) atas warga masyarakat yang lebih besar adalah ketentuan Pasal 112 Undang-Undang Republik Indonesia Nomor 32 Tahun 2009 tentang Perlindungan Dan Pengelolaan Lingkungan Hidup yang menyebutkan " Setiap pejabat berwenang yang dengan sengaja tidak melakukan pengawasan terhadap ketaatan penanggungjawab usaha dan/atau kegiatan terhadap peraturan perundang-undangan dan izin lingkungan sebagaimana dimaksud dalam pasal 71 dan pasal 72 , yang mengakibatkan terjadinya pencemaran dan/atau kerusakan lingkungan yang mengakibatkan hilangnya nyawa manusia".

Dengan demikian ketentuan pasal 112 memiliki unsur - unsur, sebagai berikut:

1. Setiap pejabat berwenang 
2. Dengan sengaja tidak melakukan pengawasan terhadap ketaatan penanggungjawab usaha dan/atau kegiatan terhadap peraturan perundangundangan dan izin lingkungan sebagaimana dimaksud dalam pasal 71 dan pasal 72, yang mengakibatkan terjadinya pencemaran dan/atau kerusakan lingkungan.

3. Mengakibatkan terjadinya pencemaran dan/atau kerusakan lingkungan.

4. Mengakibatkan hilangnya nyawa manusia.

Berdasarkan pada bunyi Undang undang sebagaimana dimaksud dalam pasal 112 tersebut diatas, maka pertanggungjawaban pidana pada pejabat pemerintahan atau pejabat negara yang diberi wewenang untuk melakukan pengawasan maupun penanggung jawab. Dari ketentuan Undang-Undang tersebut diatas, maka pelaku perbuatan dalam kasus ini adalah Setiap pejabat berwenang yakni orang yang menduduki jabatan selaku Menteri, gubernur atau bupati / walikota.

Dalam pertanggungjawaban pidana Indonesia yang menganut asas kesalahan (mens rea) yang merupakan gambaran dari asas tiada pidana tanpa kesalahan (Geen straf zonder schuld, keine strafe ohne schuld), dengan adanya asas tersebut maka untuk mempidanakan seseorang maka kesalahan harus ada pada diri pelaku / perbuatan. Dalam faka yang terjadi metode Kegiatan penambangan di kota Samarinda sebagaimana diketahui oleh pihak Pemerintah kota Samarinda harus menggunakan metode backfilling (sistem buka tutup) sebagaimana Peraturan Daerah Kota Samarinda Nomor 12 Tahun 2013 tentang Pertambangan Mineral dan Batu Bara dalam Wilayah Kota Samarinda.

Pada Pasal 34 disebutkan, "Dalam rangka memberi jaminan keselamatan dan kelestarian lingkungan, serta upaya menekan korban nyawa manusia, maka sistem pertambangan dengan metode backfilling (sistem buka tutup) wajib dilakukan oleh setiap pemegang IUP/ IUPK dan IPR. Akan tetapi dalam faktanya di tempat kejadian peristiwa hilangnya nyawa orang di lubang tambang batubara dalam penelitian penulis adalah dilubang tambang yang tidak di lakukan penutupan dan dibiarkan tetap terbuka, padahal sangat jelas di ketahui bahwa metode penambangan di kota Samarinda dengan metode buka tutup.

Sebagaimana peraturan daerah dan merupakan kewenangan Walikota Samarinda untuk melakukan pengawasannya guna memberikan sanksi administratif sebagaimana di maksud dalam pasal 89 Peraturan Daerah Kota Samarinda Nomor 12 Tahun 2013 tentang Pertambangan Mineral dan Batu Bara dalam Wilayah Kota Samarinda.

Ilmu hukum pidana, dikenal beberapa pengertian melawan hukum (wederrechtelijk) diantaranya menurut Simons, melawan hukum diartikan sebagai bertentangan dengan hukum, bukan saja terkait dengan hak orang lain (hukum subjektif), melainkan ju! 78 ncakup Hukum Perdata atau Hukur nistrasi Negara.

Menurut Vos, Moeljatno, dan Tim Pengkajian Bidang Hukum Pidana BPHN atau BABINKUMNAS dalam Rancangan KUHPN memberikan definisi "bertentangan dengan hukum" artinya, bertentangan dengan apa yang dibenarkan oleh hukum atau anggapan masyarakat, atau yang benar-benar dirasakan oleh masyarakat sebagai perbuatan yang tidak patut dilakukan. Menurut Pompe melawan hukum dibedakan menjadi 2 (dua) yakni :

a. Melawan hukum secara formel diartikan bertentangan dengan undang undang apabila suatu perbuatan telah mencocoki rumusan delik, maka biasanya dikatakan telah melawan hukum secara formel.

b. Melawan hukum materiel harus berarti hanya dalam arti negatif, artinya kalau tidak ada melawan hukum (materiel) maka merupakan dasar pembenar Dalam penjatuhan pidana harus di pakai hanya melawan hukum formel, artinya yang bertentangan dengan hukum positif yang tertulis, karena alasan asas nullum delictum noela poena sina praevia lega ponaly yang 
tercantum di dalam Pasal 1 ayat (1) KUHP. ${ }^{13}$

Dengan demikian keadaan pembiaran lubang tambang tetap terbuka yang tidak sesuai dengan metode pertambangan di Kota Samarinda sebagaimana Peraturan Daerah Kota Samarinda, maka tentunya perbuatan tersebut merupakan melawan hukum yang terdapat kesengajaan dalam hal ini Sengaja Sadar Akan Kepastian atau Keharusan (zekerheidsbewustzijn) dari pejabat yang berwenang dalam hal ini Walikota Samarinda yang seharusnya memberikan pengawasan kepada pemegang IUP atau IUPK dan IPR agar melakukan kegiatan penambangan sesuai dengan Peraturan Daerah.

\section{B. Tanggung jawab Hukum terhadap Hilangnya Nyawa Orang Di Lubang Tambang Batubara Ditinjau Dari Perspektif Hukum Pidana. (Studi kasus PT. Cahaya Energi Mandiri (CEM), Kelurahan Sambutan Kecamatan Samarinda Ilir).}

Hilangnya nyawa orang lain di lubang tambang diareal konsesi IUP PT. Cahaya Energi Mandiri (CEM), sebagaimana di uraikan diatas dapat di karenakan sebagai berikut :

a) Karena Kealfaan oleh Pemegang IUP/IUPK atau IPR.

Kealfaan yang dimaksudkan adalah tidak dilaksanakannya hal - hal yang menjadi kewajibannya sebagaimana yang telah ditetapkan dalam UndangUndang dan peraturan pemerintah serta peraturan pemerintah daerah yang ancaman hukumannya sebagaimana di maksud dalam pasal 359 KUHP yang ancaman hukumannya penjara selama-lamanya lima tahun atau kurungan selamalamanya satu tahun".

b) Karena kesengajaan oleh Pejabat yang berwenang dalam pengelolaan lingkungan hidup.

13 Andi Hamzah, 2010, Asas-Asas Hukum Pidana, Rineka Cipta; Jakarta hlm.141.
Kesengajaan tidak melakukan pengawasan sebagaimana yang seharusnya dilaksanakan atau tidak perduli terhadap lingkungan hidup dan membiarkan atau membela kealfaan yang dilakukan Pemegang IUP/IUPK atau IPR yang melakukan kegiatan pertambangan tidak sesuai dengan pengelolaan lingkungan hidup yang ancaman hukumannya dipidana dengan pidana penjara paling lama 1 (satu) tahun atau denda paling banyak Rp500.000.000,00 (lima ratus juta rupiah).

Meskipun tanggung jawab pidana terhadap perbuatan sebagaimana tersebut diatas adalah berupa ancaman pemidanaan badan terhadap pelaku dan denda kepada negara bagi pelaku yang dinyatakan bersalah, akan tetapi ketentuan dalam Undang - undang tersebut belum memberikan kepastian hukum terhadap ganti rugi keluarga korban sebagai akibat perbuatan melawan hukum oleh pelaku. Oleh karena itu ganti rugi guna memberikan jaminan perlindungan hukum terhadap korban terlebih pada kasus lubang tambang yang rata- rata korbannya adalah anak-anak di bawah umur yang memiliki hak-hak yang dijamin dalam Deklarasi Hak Anak-Anak 20 November 1958, maka upaya penyelesaian persoalan tersebut bukan hanya dengan pemidanaan badan terhadap pelaku tetapi juga pemberian restitusi kepada korban dapat di tekankan kepada pelaku sebagai bentuk tanggungjawab hukum sipelaku terhadap korban.

Hal ini selain didasarkan pada aturan juga didasarkan teori -teori yang telah berlaku Secara tradisonal, teori-teori tentang tujuan pemidanaan pada umumnya dapat dibagi dalam 2 kelompok teori, yaitu:

a. Teori absolut atau teori pembalasan (retributive/ vervelings theorien);

b. Teori relatif atau teori tujuan (utilitarian/doeltheorien) 
Dimana tujuan pemidanaan menurut teori pertama, merupakan akibat mutlak yang harus ada sebagai suatu pembalasan kepada orang yang melakukan perbuatan pidana. Jadi dasar pembenaran dari pemidanaan terletak pada adanya terjadi perbuatan pidana itu sendiri.

Teori ini muncul pada akhir abad kedelapan belas, dan Immanuel Kant, salah seorang tokoh dari teori ini berpendapat, "pidana bukan merupakan suatu alat untuk mencapai tujuan, melainkan mencerminkan keadilan." Sedangkan menurut teori kedua, tujuan pemidanaan bukanlah untuk memuaskan tuntutan absolut dari keadilan, tetapi mempunyai tujuan-tujuan tertentu yang bermanfaat. ${ }^{14}$ Untuk itu aspek keadilan dan manfaat bagi korban dan keluarganya perlu ditekankan, jika hanya menghukum pelaku dengan pidana badan saja tetapi tidak ada tanggungjawab ganti kerugian terhadap apa yang telah di derita oleh korban atau keluarganya, maka tujuan pidana dan pemidanaan kepada pelaku dapat dianggap sebagai ketidakadilan bagi korban atau keluarganya. ${ }^{15}$ Sementara keadilan harus di berikan kepada keduanya baik korban dan pelaku. Seperit halnya yang telah disampaikan Andi Mattalatta dalam kaitan ini menulis bahwa hakekat dari suatu perbuatan pidana seharusnya juga dilihat sebagai sesuatu yang merugikan pihak lain yaitu yang disebut dengan korban, karena itu pidana yang dijatuhkan kepada pelanggar harus pula memperhatikan kepentingan dari si korban dalam bentuk pemulihan kerugian yang dideritanya. ${ }^{16}$

Di negara-negara maju terutama di negara penganut sistem hukum Anglo Saxon seperti Inggris, Amerika Serikat, Australia dan New Zealand restitusi telah disahkan sebagai salah satu jenis pidana

14 Muladi dan Barda Nawawi Arief, 1992, Teori-Teori dan Kebijakan Pidana, Alumni; Bandung, Cetakan Kedua (Edisi Revisi). Hlm.10. Andi Hamzah, 1993, System Pidana dan Pemidanaan Di Indonesia, Pradnya Paramita Cetakan Kedua (Edisi Revisi); Jakarta, hlm. 26.

16 Andi Mattalatta, 1987, "Santunan Bagi Korban," Viktimologi Sebuah Bunga Rampai. J.E. Sahetapy (ed.). Jakarta: Pustaka Sinar Harapan, Cetakan Pertama. Hlm. 42. dalam peraturan perundang-undangannya. Karena itu, restitusi telah dapat diterapkan di negara-negara tersebut, dan yang paling awal melaksanakan adalah negara New Zealand mulai tahun 1963. ${ }^{17}$ Sedangkan di Indonesia Pemberian restitusi tidak diatur dalam jenis pidana namun telah diatur dalam pasal 20 Peraturan Mahkamah Agung Nomor : 13 Tahun 2016 tentang Tata Cara Penanganan Perkara Tindak Pidana oleh Korporasi dan Peraturan Pemerintah No. 44 tahun 2008 tentang Pemberian Kompensasi, Restitusi, dan Bantuan Kepada Saksi dan Korban yang diartikan sebagai ganti kerugian yang diberikan kepada Korban atau Keluarganya oleh pelaku atau pihak ketiga, dapat berupa pengembalian harta milik, pembayaran ganti kerugian untuk kehilangan atau penderitaan, atau penggantian biaya untuk tindakan tertentu.

Van der Heuvel menulis bahwa sekarang telah terjadi pergeseran perhatian. Pergeseran perhatian dan issue yang dimaksud adalah bahwa hukum pidana tidak lagi semata-mata memusatkan perhatian terhadap pelaku dan perbuatan pidananya, melainkan juga memusatkan perhatiannya terhadap konsekuensi yang mungkin timbul sebagai akibat dari perbuatan pidana yang dilakukan. ${ }^{18}$

Tanggung jawab hukum terhadap pelaku untuk memberikan restitusi kepada korban secara eksplisit sebenarnya juga telah disampaikan dalam Simposium Pembaharuan Hukum Pidana Nasional tahun 1980, yang dalam salah satu laporannya menyebutkan: ${ }^{19}$

1. Sesuai dengan politik hukum pidana, maka tujuan pemidanaan harus diarahkan kepada perlindungan masyarakat dari perbuatan pidana serta keseimbangan dan keselarasan hidup

17 Stephen Schafer, 1968, The Victim and Criminal, Random House, New York, hlm 117-118

18 Romli Atmasasmita, 1992, Masalah Santunan Terhadap Korban Tindak Pidana," Majalah Hukum Nasional Departemen Kehakiman, hlm. 55.

19 Barda Nawawi Arief, 1996, Kebijakan Legislatif Dalam Penanggulangan Kejahatan dengan Pidana Penjara, Badan Universitas Diponegoro; Semarang, Cetakan Kedua (Edisi Kedua). hlm. 82. 
dalam masyarakat dengan memperhatikan kepentingankepentingan masyarakat/ negara, korban dan pelaku.

2. Atas dasar tujuan tersebut, maka pemidanaan harus mengandung unsurunsur yang bersifat:

a. Kemanusiaan, dalam arti bahwa pemidanaan tersebut menjunjung tinggi harkat dan martabat seseorang;

b. Edukatif, dalam arti bahwa pemidanaan itu mampu membuat orang sadar sepenuhnya atas perbuatan yang dilakukan dan menyebabkan ia mempunyai sikap jiwa yang positif dan konstruktif bagi usaha penanggulangan perbuatan pidana;

c. Keadilan, dalam arti bahwa pemidanaan tersebut dirasakan adil, baik oleh si pelaku perbuatan pidana maupun oleh korban atau pun oleh masyarakat.

Untuk itu Pemberian restitusi oleh pemegang IUP/IUPK atau IPR dan Pemerintah sebagai bentuk tanggung jawab hukum karena akibat dari kesalahan yang mengakibatkan hilangnya nyawa orang lain bukanlah hal yang berada diluar konsep hukum pidana di Indonesia tetapi hal yang telah selaras dan sejalan dengan hukum pidana di Indonesia sebagai bentuk tanggung jawab hukum hal ini sebagaimana yang telah disampaikan Romli Atmasasmita, bahwa masalah restitusi kepada korban kejahatan di dalam konteks hubungan pelaku dan korban merupakan suatu perwujudan dari resosialisasi tanggung jawab pelaku sebagai warga masyarakat. Melalui proses resosialisasi dimaksudkan dan diharapkan tertanam rasa tanggung jawab sosial dalam diri si pelaku. $^{20}$

Adapun mengenai masa waktu diberikannya restitusi kepada korban tindak pidana oleh pelaku perbuatan dapat dilakukan sebelum atau setelah pelaku dinyatakan bersalah berdasarkan putusan pengadilan yang telah memperoleh kekuatan hukum tetap. Hal ini sesuai dengan Pasal 21 Peraturan Pemerintah Nomor 44 Tahun 2008 tentang Pemberian Kompensasi, Restitusi, Dan Bantuan Kepada Saksi Dan Korban yang menegaskan bahwa Pengajuan permohonan restitusi dapat dilakukan sebelum atau setelah pelaku dinyatakan bersalah berdasarkan putusan pengadilan yang telah memperoleh kekuatan hukum tetap.

\section{PENUTUP KESIMPULAN DAN SARAN}

Berdasarkan hasil penelitian dan pembahasan, dapat disimpulkan bahwa :

1. Hilangnya nyawa orang di lubang tambang batubara di Kota Samarinda dapat dipertanggungjawabkan kepada pemegang IUP/IUPK atau IPR yang telah memenuhi unsur-unsur dalam tindak Pidana, sebagaimana di maksud dalam pasal 359 KUHP yang berbunyi ; Barangsiapa karena kelalaiannya menyebabkan matinya orang. Hilangnya nyawa orang di lubang tambang batubara di Kota Samarinda dapat dipertanggungjawabkan kepada Pemerintah dalam hal ini Walikota Samarinda. Apabila Walikota tidak melakukan pengawasan sebagaimana yang seharusnya dilaksanakan atau tidak perduli terhadap lingkungan hidup dan membiarkan atau membela kealfaan yang dilakukan Pemegang IUP/IUPK atau IPR, dengan dugaan tindak pidana. Setiap pejabat berwenang yang dengan sengaja tidak melakukan pengawasan terhadap ketaatan penanggungjawab usaha dan/atau kegiatan terhadap peraturan perundang-undangan dan izin lingkungan sebagaimana dimaksud dalam pasal 71 dan pasal 72, yang mengakibatkan terjadinya pencemaran dan/atau kerusakan lingkungan yang mengakibatkan hilangnya nyawa manusia. 
Sedangkan orang tua korban sendiri tidak dapat dipertanggungjawabkan karena tanggungjawab terhadap lubang tambang atau di Tempat Kejadian Perkara (TKP) bukanlah tanggung jawab dari orang tua korban untuk melakukan pengawasannya tetapi tanggung jawab pemegang IUP/IUPK atau IPR dan pemerintah. Untuk itu Unsur kelalaiannya menyebabkan matinya orang tidak terpenuhi sedangkan menurut asas Geen straf zonder schuld, tiada pidana tanpa kesalahan, maka untuk dapat mempertanggungjawabkan suatu perbuatan harus ada kesalahan pada diri pelaku.

2. Tanggung Jawab hukum terhadap hilangnya nyawa orang di lubang tambang batubara akibat daripada kelalaian. Maka telah menjadi tanggung jawab hukum bagi pemegang IUP/IUPK atau IPR yang acamannya penjara selama-lamanya lima tahun atau kurungan selama-lamanya satu tahun. Ancaman hukuman dipidana dengan pidana penjara paling lama 1 (satu) tahun sedangkan bagi pejabat yang dengan sengaja tidak melakukan pengawasan terhadap ketaatan penanggungjawab usaha dan/atau kegiatan terhadap peraturan perundang-undangan dan izin lingkungan sebagaimana dimaksud dalam pasal 71 dan pasal 72, yang mengakibatkan terjadinya pencemaran dan/atau kerusakan lingkungan yang mengakibatkan hilangnya nyawa manusia diancam pidana denda paling banyak Rp500.000.000,00 (lima ratus juta rupiah). Selain pidana badan dan denda Pelaku perbuatan juga wajib memberikan restitusi kepada korban atau keluarganya sebagai bentuk tanggungjawab hukum kepada Korban.
Saran - saran yang dapat peneliti sampaikan sebagai bahan masukkan adalah: 1. Bagi Pemegang IUP/IUPK atau IPR.

a) Melaksanakan kewajiban untuk melakukan reklamasi dan pasca tambang berkoordinasi dengan pemerintah dan kewajiban-kewajiban yang lain sesuai perundangan undangan yang berlaku.

b) Melakukan resitusi terhadap hak-hak korban sebagai perwujudan dan penghormatan korporasi, terhadap hak asasi manusia dalam menjalankan kegiatan operasionalnya.

2. Bagi Pemerintah (Kepada Walikota dan Bupati )

a) Berkoordinasi dan membantu Gubernur Kalimantan timur dalam proses penanganan, inventarisasi, dan evaluasi keberadaan pertambangan diwilayahnya.

b) Melakukan pengawasan dan meminta kepada perusahaan untuk melaksanakan kewajiban untuk reklamasi dan pasca tambang diwilayah masing-masing.

c) Melakukan upaya pencegahan agar tidak jatuh korban berikutnya dengan memerintahkan perusahaan membuat plang peringatan, pemagaran, dan pos keamanan di area bekas tambang.

d) Melakukan tindakan kemanusiaan dengan memberikan santunan kepada keluarga korban. 


\section{DAFTAR PUSTAKA}

\section{Literatur}

Abdulkadir Muhammad, 2010, Hukum Perusahaan Indonesia, Jakarta, Citra Aditya Bakti.

Arief Nawawi Barda dan Muladi, 1992, Teori - Teori Kebijakan Pidana, Bandung, Alumni.

Asshiddiqie Jimly, 2006, Teori Hans Kelsen Tentang Hukum, Jakarta, Press.

Atmasasmita Romli, 1995, Kapita Selekta Hukum Pidana dan Kriminologi, Bandung, Mandar Maju.

Hamzah Andi, 2005, Kamus Hukum, Jakarta, Ghalia.

HS Salim, 2005, Hukum Pertambangan Di Indonesia, Jakarta, Raja Grafindo Persada.

Kanter E.Y \& S.R. Sianturi, 2002, Azas Hukum Pidana dan Penerapannya, Jakarta, Storia Grafika

M. Yahya Harahap, 2008, Pembahasan Permasalahan Dan Penerapan KUHAP: Pemeriksaan Sidang Pengadilan, Banding, Kasasi, dan Peninjauan Kembali,Jakarta, Sinar Grafika.

Mertokusumo sudikno, 1999, Mengenal Hukum Suatu Pengantar, Yogyakarta, Liberty.

Moeljatno, 2002, Asas-Asas Hukum Pidana, Jakarta, Rineka Cipta.

Mulyadi Lilik, 2007, Hukum Acara Pidana Normatif, Teoritis, Praktik dan Permasalahannya, Bandung, Alumni.

Mulyadi Mahmud, 2004, Hakekat Pertanggungjawaban Pidana Korporasi Dalam Pelestarian Lingkungan Hidup,Medan, Pustaka Bangsa Pers.

Nasution Bahder Johan, Hukum Kesehatan Pertanggungjawaban Dokter, Jakarta, Rineka Cipta.

Notoatmojo Soekidjo, 2010, Etika Dan Hukum, Jakarta, Rineka Cipta.

Prodjodikoro Wirjono, 2003,Asas-Asas Hukum Pidana Di Indonesia,Bandung, Refika Aditama.
SasangkaHari dan Lily Rosita, 2003, Hukum Pembuktian, Jakarta, Mandar Maju.

Sholeh Soeaidy dan Zulkair, 2001,Dasar Hukum Perlindungan Anak, Penerbit Cv. Jakarta Novindo Pustaka Mandiri.

Siregar Bismar dan W. Kusumah, 1986, Hukum dan Hak-Hak Anak, Jakarta, Rajawali.

Soekanto Soerjono, 2012, Pengantar Penelitian Hukum, Jakarta, UI Press.

Sunggono Bambang, 2003,Metode Penelitian Hukum, Jakarta,Raja Grafindo Persada.

Triwulan Titik Dan Shinta Febrian,2010, Perlindungan Hukum Bagi Pasien, Jakarta, Prestasi Pustaka.

Waluyadi, 2004, Hukum Pembuktian dalam Perkara Pidana untuk Mahasiswa dan Praktisi, Bandung, Mandar maju.

\section{Peraturan Perundang - undangan}

Undang - undang Dasar Negara Republik Indonesia 1945.

Undang-undang Republik Indonesia Nomor 32 Tahun 2009 tentang Perlindungan dan Pengelolaan lingkungan Hidup. (Lembaran Negara Republik Indonesia Tahun 2009 nomor 140 Tambahan Lembaran Negara Republik Indonesia Nomor : 5059 )

Undang-undang Republik Indonesia Nomor 4 Tahun 2009 tentang pertambangan mineral dan batubara. (Lembaran Negara Republik Indonesia Tahun 2009 Nomor 4 Tambahan Lembaran Negara Republik Indonesia Nomor 4959 ).

Kitab Undang - undang hukum Pidana (KUHP ). 
Peraturan menteri Lingkungan Hidup Nomor 4 Tahun 2012 tentang Indikator Ramah lingkungan Untuk Usaha dan / atau kegiatan Penambangan Terbuka Batubara.

Peraturan menteri Lingkungan Hidup Nomor 7 Tahun 2014 tentang PelaksanaanReklamasiPascatambang Pada Kegiatan Usaha Pertambangan Mineral dan Batubara.

Peraturan Pemerintah Republik Indonesia No 78 Tahun 2010 Tentang Reklamasi dan Pascatambang.

Peraturan Daerah Nomor 8 Tahun 2013 Tentang Penyelenggaraan Reklamasi dan Pascatambang.

Peraturan Gubernur Nomor 53 Tahun 2015 Tentang komisi Pengawas Reklamasi dan Pascatambang Daerah.

\section{Dokumen Hukum, Skripsi, dan Tesis}

Komnas Ham, Jatam dan Koalisi Advokasi Kasus Lubang Tambang, Pelanggaran Hak Asasi Manusia Dalam Kasus Eks lubang Tambang Batubara di Kalimantan Timur, Komnas Ham

Muchsin, 2003, Perlindungan dan Kepastian Hukum bagi Investor di Indonesia, magister Ilmu Hukum Program Pascasarjana Universitas Sebelas Maret,Surakarta diakses tanggal 04 maret 2017 pukul 13.00 Wita.

Satjipto Raharjo, 1993, Penyelenggaraan Keadilan dalam Masyarakat yang sedang Berubah, Jurnal Masalah Hukum diakses tanggal 04 maret 2017 pukul 14.30 Wita.

Database Jatam Kalimantan Timur 2011 2016
Website

http://journal.uad.ac.id/index.php/Novelty/a rticle/download/3932/2196.Diakses Pada Tanggal 10 maret 2017, Pukul 14.00 Wita.

Uud1945https://www.academia.edu/883606 7/penjelasan dari isi uud 1945 pasal 28 diakses pada tanggal 22 februari 2017

http://tesishukum.com/pengertianperlindun gan-hukum-menurut-para-ahli/di akses pada tanggal 4 Maret 2017 